\title{
Risk Management of Insurance Fund Use in the Large Asset Management
}

\section{Era}

\author{
Yalan $\mathrm{Hu}^{1,2}$ \\ ${ }^{1}$ School of Finance, Zhongnan University of Economics and Law, Wuhan, Hubei, 430074, China \\ ${ }^{2}$ School of Economics, South-Central University for Nationalities, Wuhan, Hubei, 430074, China \\ huyalan@126.com
}

Keywords: Large Asset Management; Insurance Funds; Risk Control

\begin{abstract}
With the deepening of Chinese economic reform, the liberalization of national policy in the asset management industry breaks the competition barriers in securities, futures, securities investment fund management companies, banks, insurance and trust companies, and makes the asset management ind ustry enter the large asset management era with further competition, innovation and mixed management. In the new era, how to improve the risk management of fund utilization is a major difficulty confronted by the insurance industry. This paper tracks the development of the insurance industry, discovers existing problems of fund utilization in the insurance industry, grasp the basic principle of fund utilization in the insurance companies and general rules of risk control, combines with the characteristics of large as set management era, and gives certain improvement opinions on the risk control of insurance fund utilization in the large asset management era. In recent years, the Chinese government has launched various policies, relaxes the regulation of the asset management industry, breaks the competition barriers of securities, futures, securities investment fund management companies, banks, insurance and trust companies in reducing related restrictions, and makes the asset management industry enter the large asset management era with further competition, innovation and mixed management. The era brings an unprecedented opportunity for the insurance funds utilization as well as many risks. In this era, the risk control of insurance fund utilization is of great significance to the insurance companies.
\end{abstract}

\section{Large Information Management Era}

From the second half of 2012, the re gulatory authorities carried out a new round of deregulation and innovative policy over the asset management industry, and thus large asset management era emerged in response to the proper time and conditions. Large asset management means that the asset management industry has entered the mixed operation era with diversified main body, diversified product innovation and fierce competition.

Performance of Large Information Management Era. The first is liberalization of asset management policies, reduced government intervention and dominance returning to the market. Since 2012, China Securities Regulatory Commission, China Insurance Regulatory Commission and China Banking Regulatory Commission gradually liberalize the asset management policies in the fields of futures, funds, insurance, securities and banking. On May 22 in the same year, China Securities Regulatory Commission issued Measures of Futures Asset Management Business Pilot; on 
October 22, China Insurance Regulatory Commission also issued Notice on Related Matters of Insurance Asset Management Companies; in 2013, China Insurance Regulatory Commission carried out the liberalization policies over the banking asset management business, approved 11 domestic commercial banks to carry out financial asset management business pilots, also conduct the pilot of direct debt financing instruments, and the first amount was about 20 billion Yuan. This measure has pointed out the characteristics of policy liberalization in the large asset management era.

The second performance is the fierce competition in the asset management industry and consumers can choose more products. With further deregulation, increased competition body and liberalized scope of investment, all contribute to innovative products. Before the asset management policy liberalization, trusts and foundations have basically monopolized the asset management market, and the product homogeneity is more serious. After the policy liberalization, the asset management body increases, they have their own strengths, and the product range is also increased. Therefore, various types of products have done their best, indicating the competition becomes fierce in the asset management industry.

Impacts of Large Asset Management Era on Insurance Fund Utilization. The arrival of large asset management era is both an opportunity and a challenge for the insurance companies. The insurers face the opportunity of larger return on insurance fund investment. Before 2004, the insurance fund utilization could only achieve return on investment through bank deposits or fixed income products and other non-equity assets, and return on investment rate remained at a low level. In September 2004, the insurance fund can directly enter the market by purchasing stocks, and the return on insurance fund investment is substantially increased. When the market penetration of insurance fund becomes strong, the return on insurer investment must be increased significantly. For insurance companies, if the investment income increases, the premium will be reduced; the consumer attractiveness increases, the premium volume enters an upward trend, and forms a virtuous circle.

Similarly, the insurance companies are also facing great challenges in the large asset management era. The first is enhanced competition. Financial products of insurance company gradually fade away their traditional advantages in this new round of large asset management era. How to produce more competitive products based on industrial features is a magic weapon for the success of future large asset management era and various financial agencies. The second is the increased market risks faced by insurance companies. With the deregulation of investment channels and investment instruments also makes the insurance companies face a wider range of financial risks, stability and security are challenged, and greatly influenced by macro-economy and fluctuations of market change.

\section{Risk Types of Insurance Fund Utilization in the Large Asset Management Era}

Risk is ubiquitous in the world, which is a result different from expected results. The reason for the existence of the insurance company is the existence of risks. Similarly, as a company, the insurance companies also face many risks, which are specifically divided into four categories.

Credit Risk. Credit risks faced by insurance companies refer to the institutional credit risks having transactions with the investment business with insurance companies. When the investment institutions cannot perform or are unwilling to fulfill the original contract, the credit risk will occur, and the investment income of insurance companies will be affected. In the large asset management era, the insurance companies have more widely investment objects. In the broad market, the bad is mixed with the good, so the insurance companies must carefully select in the investment process, 
determine the as set credit of collaborating objects, predict its possibilities of default, and guarantee the safety of insurance fund utilization.

Market Risks. Market changes bring adverse effect to the insurance companies, namely, the market risks faced by the insurance companies. With the advent of large asset management era, insurance fund utilization channel liberalization at the government policy level has improved the insurance fund utilization efficiency, and also increased the exposure breadth and depth of the insurance funds in the market. Since Decisions on Modification of Provisional Regulations of Insurance Fund Utilization Management of China Insurance Regulatory Commission was implemented on May 1, 2014 allows that the insurance companies to buy and sell bonds, stocks, securities investment fund shares and other marketable securities, which greatly increases the market risks faced by insurance fund utilization.

Liquidity Risks. Liquidity risks faced by insurance companies consist of fund utilization liquidity risks and insurance business liquidity risks. Fund utilization liquidity risks refer to the ability of fund realization or external financing for repayment of debts due. As mentioned above, the insurance company's assets have liabilities, which need adequate liquid funds to cope with the compensation caused by unexpected accidents. In the large asset management era, investment channels of the insurance companies are expanded, and investors may invest in real estate and other long-term projects. Real estate investment is characterized by huge amount, long time of cost recovery and large earnings risk, which proposes high demands for the fund utilization liquidity of insurance companies. If the insurance companies hold poor liquid assets, have to sell part of assets at a low price in the face of compensation. If the outstanding bonds or temporary fund raising at high costs to meet the payment needs, it will have serious impacts on the stable operation of insurance companies.

\section{Current Situation and Deficiencies of Risk Control of Insurance Fund Utilization}

Risk control of insurance fund utilization is the most important link in the business management process of the insurance companies. It is an integrated control and treatment strategy for various insurance fund utilization risks based on scientific prediction and measurement risks as well as the protection of insurance fund utilization safety.

At present, the fund investment operating channel of the Chinese insurance companies is roughly divided into four categories - bank deposits, bonds, securities investment funds and stocks. The insurance fund application conditions in 2013 are as below: bank deposits 2.264098 trillion Yuan, accounting for 29.45\%; bonds 3.337542 trillion Yuan, accounting for 43.42\%; stocks and securities investment funds 786.482 billion Yuan, accounting for $10.23 \%$; other investments 1.299219 trillion Yuan, accounting for $16.9 \%$; The insurance fund utilization condition in 2014 are as follows: bank deposits 2.531073 trillion Yuan, accounting for 27.12\%; bonds 3.559971 trillion Yuan, accounting for 38.15\%; stocks and securities investment funds 1.032558 trillion Yuan, accounting for 11.06\%; other investments 2207.841 billion Yuan, accounting for $23.67 \%$. Such insurance fund utilization structure is unfavorable for economic development and long-term business development. When using the insurance funds, the insurance companies are over-reliance on bank deposits and bond investments, and are conservative in other investments. From the experience of developed insurance countries, the future long-term development choice is to use the investment portfolio diversification, make up losses and gain profits. Although the insurance fund channel is expanded in recent years, the investment ratio and type of insurance companies are changed significantly, yet the liberalization is still insufficient. From the current asset structure of insurance companies investment, the bank 
deposits and bonds account for a very high proportion in total assets, these fixed-rate product rate has high sensitivity, they are obviously affected by monetary policy and interest rate trend, so it is difficult to avoid larger interest rate risks in the risk control.

In addition to interest rate risks caused by unreasonable fund investment structure, the insurance fund utilization also faces the credit risk incurred from imperfect credit rating mechanism. At present, among 50 largest commercial insurers in the world, only three companies are not officially rated, 35 companies have been officially rated, and 12 companies have been rated in public. However, in China, due to the immature market, the information disclosure degree is far from reaching the credit assessment degree. Besides, because the credit rating agencies do not have complete independence, their assessment results often show the color of interests, and do not have sufficient trust, and thus the Chinese insurance companies also pay little attention to credit rating in such background. However, with the gradual expansion of insurance fund utilization scope and the broaden transaction objects, the credit rating over transaction object is imperative.

At present, the internal risk control system of insurance fund utilization also needs further improvement. The Chinese insurance fund utilization has three modes. Firstly, the insurance companies set up their own independent asset management companies to manage the funds; secondly, they have no ability or ordinary size of assets, they entrust professional asset management institutions to manage funds; thirdly, they have small asset size, it is unnecessary to independently set up asset management companies, so they set up fund utilization department in the insurance companies to invest and use the corporate funds. However, regardless of any mode, the insurance companies are decision makers and stakeholders, and they are main body in the face of risks. Therefore, it is very important to choose the insurance fund utilization mode. From the experience of developed insurance countries, it is not an optimal choice for insurance companies to control the investment risks by completely entrusting external agencies to manage funds. Among Fortune Global 500 enterprises and 34 stock insurance companies, more than 20 companies adopt professional insurance asset management mode to manage the insurance funds. If the insurance companies set up a fund utilization department to manage the insurance funds, it is not a long-term choice. With the expansion of business assets, the department management model is inconsistent with large-scale fund utilization needs. Besides, the fund utilization department has reduced the level of asset management, so it is hard to improve the competitiveness. In contrast, professional insurance asset management mode can effectively enhance the business management capability of insurance assets, and improve the fund utilization rate.

\section{Suggestions}

The insurance fund use risks finally belong to the management problems during the operation process of insurance companies. Regardless of fund use method or fund use channels, the insurance companies are the first defense line of risks. Therefore, it is essential to start from the entire fund utilization risk control process at the company level, improve and strengthen each process, and build effective risk warning mechanism.

Corporate Autonomous Control. Training of Professional Talents:

Talent is a strength source of business growth or continued prosperity. In today's knowledge explosion society, talents who can keep learning and progressing are the backbone required by enterprises. The enterprises train and introduce talents, make rational use of them, improve their knowledge productivity, bring more benefits to enterprises through knowledge, and thus enhance the 
core competitiveness of enterprises. First, build reasonable talent introduction mechanism. Today talents in the insurance industry are uneven, the professional insurance talents are insufficient, and high-end actuary talents have a huge gap. Therefore, in the face of this talent structure imbalance, insurance companies need to establish a reasonable talent introduction mechanism to enhance competitiveness. Second, build a strong talent training mechanism. Talent training is divided into internal selection and external collaborative training. In terms of internal selection, stick to implementing the value-oriented, competition-oriented, people-oriented and people-oriented internal human resource market reform, build a scientific and rational selection mechanism, assessment mechanism and distribution mechanism, and give full play to the internal roles of market competition, motivation and elimination. In terms of external collaborative training, the enterprises may cooperate with universities, give appropriate guidance and internship opportunities for the training of insurance talents, make enterprises further contact students, and foster high-end talents in compliance with business development.

Optimizing the Fund Investment Portfolio and Improve the Risk Prevention Level:

The arrival of large asset management era has expanded the investment channel of insurance companies, so the insurance companies need to change the traditional concepts of investment decision-making, relieve from over-reliance on bank deposits and bond investments, increase the proportion of other investments and stock funds, enrich and optimize the investment portfolio. In addition, grasp the key points between fund utilization security and profitability, ensure security of the insurance fund utilization, and effectively improve the return on insurance fund utilization.

Improve Internal Risk Control Level:

Fund utilization is characterized by complicated decision-making, management, supervision and operation procedures, multiple links, a wide range, a large number of talents and great risk. Therefore, it is necessary to control the risks along the main line, and build a strict internal control system. On the one hand, these systems must cover all areas of investment, investment instruments, investment tools, each operation link and jobs; on the other hand, establish a organizational structure with clear division, so that everyone will know their duties, powers and work flow, strictly abide by regulations, ensure that all investment activities can be effectively supervised, comply with established procedures, and ensure that the investment strategies and objectives of the Board of Directors can be realized smoothly.

Government Regulation: Building a Good Legal Environment for Insurance Fund Utilization. First, modify Insurance Act, further broaden the fund utilization channels, and leave some space. Secondly, complement the development of the rules and regulations for the approved services, such as Regulations on Insurance Asset Management Company. Thirdly, specify the qualifications over the insurance investment executives and specific operators; define the basic credit rating standard for banks, securities, funds, trusts and other trading partners; determine the duties and standards of asset client, the consignee and the trustee. Fourthly, before expanding the investment patterns, opening the investment field and increasing the investment instruments and tools, there shall be a long period of preparation time, draw on foreign experience according to national conditions, and make repeated discussions and arguments, if necessary, hold a hearing, listen to various opinions, and develop regulatory rules.

Secondly, the division of insurance fund utilization scope has broadened the insurance fund utilization channel, which does not mean any scope limit and all-round liberalization. The enterprises shall stand on international and domestic economic and financial operating environments, combine 
with the special nature of insurance business risks, follow the safety, liquidity and profitability requirements of insurance fund utilization, learn from the successful experience of foreign countries, and gradually liberalize the field and scope of insurance fund utilization. The following limitations may be liberalized: First, liberalize the control of existing investment instrument ratio, and further liberalize the restriction of corporate bond purchase and increase the proportion of investment in the stock market. Secondly, make breakthroughs in the key state infrastructure and industrial investment, particularly investment in water, electricity, transportation, telecommunications, energy, and so on. Thirdly, allow to handle loan business at the appropriate time. Fourthly, liberalize cross-shareholding limit with financial institutions for equity investment. Fifthly, moderately allow to invest in financial derivative products and enable insurance companies to effectively avoid risks through hedging. Liberalization of the insurance investment channels should be gradual, various factors should be considered, be liberalized, avoid the past chaos, pay attention to prevention of insurance risks, resolutely put an end to serious impacts of improper investment on solvency of insurance companies, and earnestly safeguard the interests of the insured. In addition, unlisted stocks and non-collateral loans with poor liquidity and higher risk are prohibited, and speculative investment in derivative financial products is also prohibited.

\section{References}

[1] M. S. Jiang, Research on Current Situation, Problems and Countermeasures of Insurance Asset Management Development in China. Scientific Decision. 4885. 2014.10.

[2] L. L. Deng, Research on Current Situation, Problems and Countermeasures of Insurance Fund Investment Use in China. East China Normal University[Dissertation]. 2012.

[3] P. Hu, Seek Great Development Path with the "Opportunity" of Large Asset Management. The Financial Times, May 29, 2014 (5th Edition)

[4] H. X. Su, Transformation Direction and Talent Training of Life Insurance Industry in the Large Asset Management Era. Shanghai Securities News, December 3, 2014 (A04th Edition)

[5] X. R. Han, D. P. Wang, Insurance Solutions in the Large Asset Management Era. Observing and Thinking. May 2014.

[6] D. F. Babbel, Investment Management of Insurance Companies. Economic Science Press, Beijing. 2010.

[7] China International Capital Corporation Limited, Industry Trends Research Report, 2010 (8)

[8] Y. Song, Large Insurance Moves toward Large Asset Management. China Business News, January 6, 2014 (B07th Edition)

[9] China Insurance Yearbook, 2013 